\title{
MENGGAGAS MODEL RESTORATIVE JUSTICE TERHADAP TINDAK PIDANA MARITAL RAPE DALAM MEMBENTUK PERLINDUNGAN TERHADAP PEREMPUAN YANG SESUAI DENGAN NORMA HUKUM DI INDONESIA
}

\author{
Oleh : \\ Wahyu Beny Mukti Setiyawan, $\mathrm{SH}, \mathrm{MH}$ \\ Hadi Mahmud, $\mathrm{SH}, \mathrm{MH}$ \\ Dosen Fakultas Hukum Universitas Islam Batik Surakarta \\ Email : muktibeny@gmail.com, Hp : 081-22-545-6644
}

\begin{abstract}
Abstraksi
Indonesia merupakan Negara hukum. Hukum bertujuan untuk menciptakan perdamaian dan ketentraman dalam kehidupan bermasyarakat. Tetapi dalam kenyataannya banyak sekali penyelewengan yang terjadi di masyarakat. Salah satu contohnya yaitu kasus kejahatan dalam berumah tangga. Kekerasan Dalam Rumah Tangga (KDRT) sebenarnya telah diatur dalam Undang-Undang Nomor 23 Tahun 2004 yang mengatur tentang penghapusan kekerasan dalam rumah tangga. Kejahatan rumah tangga yang paling merusak keutuhan rumah tangga salah satunya yaitu kasus marital rape. Sedangkan dalam Undang-undang Kekerasan Dalam Rumah Tangga (KDRT) belum mengatur khusus tentang atau masalah marital rape. Ada cara yang sangat membantu untuk mengatasi masalah marital rape yaitu dengan metode pendekatan restorative justice. Dengan pendekatan model ini, maka masalah marital rape akan terpecahkan karena tujuan dari model restorative justice ini mengutamakan suatu keadilan dan pemulihan masalah tanpa jalur pidana. Restorative justice akan berhasil dilaksanakan di masyarakat jika memperhatikan norma-norma yang ada di masyarakat terkhusus Norma Hukum. Untuk itu, dibutuhkan sosialisasi tentang restorative justice di kalangan masyarakat agar pelaksanaan restorative justice bisa menyelesaikan kasus marial rape di indonesia. Penyelesaian kasus marital rape dengan metode pendekatan restorative justice dapat berupa memberikan solusi dengan konsultasi psikologi, jika cara tersebut belum berhasil, bisa menggunakan cara hukum, dimana korban bisa menggugat cerai si pelaku, dan jika si korban mengalami kekerasan fisik yang dilakukan pelaku, korban bisa mendapatkan bantuan medis.
\end{abstract}

Kata kunci : Restorative Justice, Marital Rape, Perlindungan terhadap perempuan, Norma Hukum 


\title{
REVIEW RESTORATIVE JUSTICE MODEL TOWARDS CRIMINAL ACT OF MARITAL RAPE TO BUILD LEGAL PROTECTION AGAINST WOMAN WHICH APPROPRIATE WITH LEGAL NORM IN INDONESIA
}

\author{
By : \\ Wahyu Beny Mukti Setiyawan, SH, MH \\ Hadi Mahmud, SH, MH \\ Lecturer Faculty of Law University of Islam Batik Surakarta \\ Email:muktibeny@gmail.com ,Hp :081-22-545-6644
}

\begin{abstract}
Indonesia is a Nation of law. The aim of law is to create peace and tranquility in social life. But in the reality many once misappropriation that occurred in society. For instance in case of crime in household. Domestic Violence (KDRT) actually has arranged in Constitution Number 23 of 2004 that governing abolishment violence in household. One of the most factor which demage households integrity is case in marital rape. While in Constitution Domestic Violence (KDRT) there is no special regulation yet against marital rape. There is a really helpfull way to resolve marital rape with approach restorative justice method. With approach this model, then problem marital rape will solved because aim of this restorative justice model give priority for a justice and recovery problem without criminal law. Restorative justice will successful held in community if pay attention norms that exist in community especially the Legal Norms. Therefore socialization about restorative justice are needed in circles community for implementing restorative justice in order to solve case of marital rape in Indonesia. Settlement of marital rape with restorative justice approach method could actualized through psychology consultation, if that way not successful yet, the victim could take litigation way, where she could divorce the perpetrator, and if the victim has experience Physical violence by perpetrators, the victims could acquired medical aid.
\end{abstract}

Keyword: Restorative Justice, Marital Rape, Protection to women, Norms of Law 


\section{A. PENDAHULUAN}

Negara indonesia adalah negara hukum. Hukum adalah himpunan petunjuk-petunjuk hidup (perintah-perintah dan larangan-larangan) yang mengatur tata tertib dalam suatu masyarakat, dan oleh karena itu seharusnya ditaati oleh anggota-anggota masyarakat yang bersangkutan. Selain itu, segala aspek kehidupan sebagian besar diatur dalam Norma. Norma adalah petunjuk hidup, yaitu petunjuk bagaimana kita berbuat dan bertingkah laku didalam masyarakat. Setiap orang hendaknya menaati norma atau kaidah itu agar dapat hidup tenteram dan damai (Utrech, Pengantar Dalam Hukum Indonesia, ikhtiar, Jakarta, cet. IV, 1987, hal. 09), Kedua hal tersebut sangatlah penting untuk menata kehidupan bermasyarakat. Rakyat indonesia seharusnya paham akan nilai yang terkandung dalam norma masyarakat.
Tetapi dalam kenyataanya banyak sekali kejahatankejahatan yang terjadi di kehidupan masyarakat, sebagai contohnya yaitu Kekerasan Dalam Rumah Tangga (KDRT). Kekerasan Dalam Rumah Tangga adalah tindakan yang dilakukan di dalam rumah tangga baik oleh suami, istri, maupun anak yang berdampak buruk terhadap keutuhan fisik, psikis, dan keharmonisan. Yang merupakan lingkup tindakan Kekerasan Dalam Rumah Tangga (KDRT) adalah perbuatan terhadap seseorang terutama perempuan, yang berakibat timbulnya kesengsaraan atau penderitaan secara fisik, seksual, psikologis, dan/atau penelantaran rumah tangga termasuk ancaman untuk melakukan perbuatan, pemaksaan, atau perampasan kemerdekaan secara melawan hukum dalam lingkup rumah tangga. Sebagian besar korban Kekerasan Dalam Rumah Tangga (KDRT) adalah kaum perempuan (istri) dan pelakunya adalah suami. 
Tidak semua tindakan KDRT dapat ditangani secara tuntas karena korban sering menutup-nutupi dengan alasan ikatan struktur budaya, agama dan belum dipahaminya sistem hukum yang berlaku. Padahal perlindungan oleh negara dan masyarakat bertujuan untuk memberi rasa aman terhadap korban serta pelakunya. Salah satu bagian dari Kekerasan Dalam Rumah Tangga (KDRT) yang sangat membahayakan kelangsungan kehidupan berumah tangga adalah marital rape. Marital rape dapat diartikan sebagai pemerkosaan dalam hubungan perkawinan. Kasus ini memang sudah terjadi di bangsa kita, oleh karena itu pihak yang berwajib seharusnya menggagas masalah kejahatan dalam berumah tangga ini. Seperti yang dijelaskan pada Undang-Undang Nomor 23 Tahun 2004 huruf d yaitu "bahwa dalam kenyataannya kasus kekerasan dalam rumah tangga banyak terjadi, sedangkan sistem hukum di Indonesia belum menjamin perlindungan terhadap korban kekerasan dalam rumah tangga" (Undang-Undang Nomor 23 Tahun 2004 tentang Penghapusan Kekerasan Dalam Rumah Tangga (KDRT)).

Terkadang tindak pidana tidak menyelesaikan masalah yang sudah terjadi di masyarakat ini baik dari pelaku maupun dari korban tindak kekerasan. Padahal ada jalan lain yang harus diperhatikan oleh pemerintah tentang masalah ini yaitu dengan model Restorative Justice. Sehubungan dengan latar belakang yang telah diuraikan sebagaimana diatas, maka penulis bermaksud mengkaji bagaimana model restorative justice terhadap marital rape guna memberi perlindungan terhadap perempuan yang sesuai dengan Norma Hukum di Indonesia.

\section{B. METODE PENELITIAN}

\section{Jenis Penelitian}

Jenis penelitian ini adalah penelitian hukum normatif atau doktrinal. Hutchinson 
sebagaimana dikutip Peter Mahmud Marzuki

mendefinisikan penelitian hukum doktrinal sebagai berikut, "Doctrinal Reseach : Reseach wich provides a systematic exposition of rules governing a particular legal category, analyses the relationship between rules, explain areas of difficulty and perhaps, predict future development (Terjemahan bebas : Penelitian Doktrinal : Penelitian yang memberikan penjelasan sistematis aturan yang mengatur suatu kategori hukum tertentu, menganalisis hubungan antara peraturan, menjelaskan daerah kesulitan dan mungkin, memprediksi pembangunan masa depan)" (Peter Mahmud Marzuki, 2010 : 32).

2. Jenis dan Sumber Bahan Hukum

Dalam penelitian hukum tidak mengenal adanya data, yang ada dalam penelitian hukum adalah bahan hukum. Bahan hukum terdiri dari bahan hukum primer, bahan hukum sekunder dan bahan hukum tersier. Bahan hukum primer yakni bahan hukum yang terdiri atas peraturan perundang-undangan berdasarkan hierarkinya. Bahan hukum sekunder adalah bahan hukum yang terdiri atas buku-buku teks (textbooks) yang ditulis oleh para ahli hukum yang berpengaruh (de herseende leer), jurnal-jurnal hukum, pendapat para sarjana, kasus-kasus hukum, yurisprudensi, dan hasil-hasil simposium mutakhir yang berkaitan dengan topik penelitian. Bahan hukum tersier adalah bahan hukum yang memberikan petunjuk atau penjelasan terhadap bahan hukum primer dan bahan hukum sekunder, seperti kamus hukum, encyclopedia, dan lain-lain (Johnny Ibrahim, 2006 : 295296). 


\section{Teknik Pengumpulan}

\section{Bahan Hukum}

Teknik pengumpulan bahan hukum dalam penelitian ini adalah menggunakan teknik studi pustaka (collecting by library). Pengumpulan bahan hukum primer, bahan hukum sekunder dan bahan hukum tersier diinventarisasi dan diklasiikasi dengan menyesuaikan masalah yang dibahas. Bahan hukum yang berhubungan dengan masalah yang dibahas dipaparkan, disistematisasi, kemudian dianalisis untuk menginterpretasikan hukum yang berlaku (Johnny Ibrahim, 2006 : 296).

\section{Teknik Analisis Bahan Hukum}

Teknik analisis bahan hukum yang digunakan dalam penelitian hukum ini adalah dengan logika deduktif. Dalam hal ini, sumber penelitian yang diperoleh dalam penelitian ini dengan melakukan inventarisasi sekaligus mengkaji dari penelitian studi kepustakaan, aturan perundang-undangan beserta dokumen-dokumen yang dapat membantu menafsirkan norma terkait, kemudian sumber penelitian tersebut diolah dan dianalisis untuk menjawab permasalahan yang diteliti. Tahap akhir adalah menarik kesimpulan dari sumber penelitian yang diolah. Menurut Philipus M. Hadjon sebagaimana dikutip oleh Peter Mahmud Marzuki, metode deduksi sebagaimana silogisme yang diajarkan oleh Aristoteles penggunaan metode deduksi berpangkan dari pengajuan premis mayor (pernyataan bersifat umum). Kemudian diajukan premis minor (bersifat khusus). Dari kedua premis itu kemudian ditarik suatu kesimpulan atau conclusion (Peter Mahmud Marzuki, 2010 : 47). Di dalam logika silogistik untuk penalaran hukum yang bersifat premis mayor adalah aturan hukum sedangkan premis minornya adalah fakta 
hukum. Sedangkan menurut Johnny Ibrahim, mengutip pendapat Bernand Arief Shiharta, logika deduktif merupakan suatu teknik untuk menarik kesimpulan dari hal yang bersifat umum menjadi khusus yang bersifat individual (Johnny Ibrahim, 2006 : 249).

\section{PEMBAHASAN}

Dalam

perkawinan, hubungan seksual menjadi aktivitas sah suami-istri dan dilakukan demi menghasilkan keturunan, memenuhi hasrat seks dan menaati perintah Tuhan atau sunnah Rasul (QS. Al-Baqarah (2) : 187, QS. AnNisa (4) : 19 dan Andy Dermawan, 2015 : 295). Kekerasan seksual terhadap perempuan memiliki dua arti. Pertama, secara umum sebagai kekerasan berdasar gender atau gender based violence, dan kedua, secara khusus sebagai bentuk tertentu dari kekerasan terhadap perempuan, yaitu kekerasan berdasar gender yang mengakibatkan kesengsaraan atau penderitaan pada perempuan secara seksual. Kekerasan dalam rumah tangga atau domestic violence dan lebih spesifik lagi wife abuse (kesewenang-wenangan terhadap istri), tetaplah menjadi sebuah "rahasia perkawinan" yang sulit dijangkau oleh kekuasaan hukum mana saja. Bahkan, sampai hari ini, disokong oleh penafsiran keagamaan yang "bias laki-laki", sebagai kalangan masih memperbolehkan memukul istri (termasuk bila ia menolak diajak bersenggama) meski dengan derajat rasa sakit yang harus ringan.

Yang mesti dicermati di sini bukanlah kadar sakit yang mesti ditanggung istri, melainkan perasaan berhak yang ada di benak suami yang memukul istrinya tadi (Siti Ruhaini Dzuhayatin, 2013 : 120-123). Kekerasaan dalam rumah tangga hingga saat ini tampak kurang mendapat perhatian serius di kalangan masyarakat. Beberapa asalan bisa 
dikemukakan di sini, di antaranya : pertama, kekerasaan dalam rumah tangga cenderung ditutupi karena rumah tangga adalah area "privat". Kedua, kekerasan dalam rumah tangga sering dianggap wajar karena memperlakukan istri sekehendak suami masih saja dianggap bahkan diyakini sebagai hak suami sebagai pemimpin dan kepala rumah tangga. Ketiga, kekerasan dalam rumah tangga itu terjadi dalam sebuah lembaga yang sah, yaitu perkawinan. Kenyataan ini selanjutnya membuat masyarakat abai dan tak sadar, bahkan muncul pandangan yang keliru bahwa suami sebisanya harus mengendalikan istri (Aroma Elmina Martha, Perempuan, $2015: 30$ ).

Kitab Undang-Undang Hukum Pidana (KUHP) tidak secara khusus melindungi alat reproduksi perempuan, terutama Pasal 285 tentang pemerkosaan yang berbunyi : "siapa dengan kekerasan atau ancaman kekerasan memaksa perempuan yang bukan istrinya bersetubuh dengan dia, dihukum karena memerkosa, dengan hukuman penjara selama-lamanya 12 tahun" (R. Soesilo, 1996 : 210). Jika dicermati, rumusan Pasal 285 KUHP tentang delik pemerkosaan di atas menyimpan sebuah anggapan bahwa dalam berhubungan seks seorang istri harus tunduk sepenuhnya kepada suami. Oleh karena itu, seorang istri tidak bisa mengadukan suaminya bila terjadi hubungan seks tanpa persetujuannya. Hal ini kemudian memunculkan perdebatan panjang seputar soal pemerkosaan yang terjadi dalam ikatan perkawinan atau yang lebih sering disebut dengan marital rape. Pemerkosaan dalam rumah tangga nyata-nyata melanggar hak istri karena seks adalah juga haknya.

Hukum islam tampaknya belum mengakomodir masalah kontroversial ini, salah satunya karena tidak ada nash yang Jurnal Ius Constituendum | Volume 3 Nomor 1 April 201875 
secara khusus memberikan penjelasan tentangnya. Bahkan, ada sebuah hadits yang berbunyi begini : "Jika suami mengajak istrinya senggama dan istrinya menolak maka para malaikat mengutuk istri tadi sampai pagi" (Iman Muslim dan Shahih Muslim, 1992 : 1436). Banyak ulama menyarankan agar hadits pertama tidak dipahami secara harfiah. Mustafa Muhammad Imarah, misalnya mengatakan bahwa laknat malaikat itu muncul bila penolakan istri dilakukan "tanpa alasan". Sedang Wahbah azZuhaili berpendapat bahwa laknat itu terjadi apabila istri menolak senggama, padahal ia "sedang longgar dan tidak takut disakiti" (Wahbah az-Zuhaili, 1989 : 335). Alhasil, pada prinsipnya seorang suami itu tidak boleh memaksakan kehendak kepada istrinya, khususnya terkait perkara seksualitas. Memaksa berarti memperlakkan pasangan secara tidak manusiawi dan memandangnya tidak lebih sekedar objek pemenuhan nafsu seks. Hal ini adalah tindak pidana pemerkosaan, yakni pemerkosaan dalam ikatan perkawinan (marital rape).

Di Indonesia, persoalan marital rape masih menjadi perdebatan. KUHP sendiri tidak menyebutkan status dan sanksi hukumnya, hingga masyarakatpun tidak meresponsnya. Padahal, bila masalah ini dibiarkan dan tidak ditangani, kaum perempuan terus akan dirugikan dan dilukai, fisik maupun psikisnya. Perempuan yang secara berulang dan berkelanjutan menjadi korban pemerkosaan suaminya akan terjangkiti beberapa karakter, antara lain : (1) inferior (merasa rendah diri) dan tidak percaya diri, (2) kerap dan selalu merasa bersalah, dan (3) menderita gangguan reproduksi akibat perasaan tertekan atau stress, seperti infertilitas (kurang mampu menghasilkan keturunan) dan kacaunya siklus haid (Elli Nur Hayati, 2000 : 49).

Marital rape hingga saat ini belum mendapat perhatian serius dari aparat penegak lume 3 Nomor 1 April 201876 
hukum maupun pemerintahan, khususnya lagi dalam hal perlindungan terhadap hak-hak korban dan memberi hukuman setimpal bagi pelaku. Walaupun Undang-Undang Republik Indonesia Nomor 23 Tahun 2004 tentang Penghapusan Kekerasan dalam Rumah Tanga (UU KDRT) telah disahkan, namun terutama dalam Pasal 46 yang mengatur soal sanksi tidak menyebutkan hukuman minimal sehingga hukuman yang dijatuhkan hakim kepada pelaku cenderung masih jauh dari rasa keadilan. Setiap perkawinan diharapkan berlangsung kekal dalam arti putusnya perkawinan hanya disebabkan oleh suatu kematian sesuai kehendak tuhan, bukan oleh sebab lain. Jika kemudian timbul suatu perselisihan tersebut di usahakan agar dapat diatasi. Disini, penulis akan menggagas model restorative justice untuk menanggulagi masalah marital rape yang dapat sesuai dan adil untuk pelaku maupun korban. Konsep pendekatan restorative justice merupakan suatu pendekatan yang lebih menitik-beratkan pada kondisi terciptanya keadilan dan keseimbangan bagi pelaku tindak pidana serta korbannya sendiri.

Mekanisme tata acara dan peradilan pidana yang berfokus pada pemidanaan diubah menjadi proses dialog dan mediasi untuk menciptakan kesepakatan atas penyelesaian perkara pidana yang lebih adil dan seimbang bagi pihak korban maupun pelaku (http://www.hukumonline.com/b erita/baca/lt4e25360a422c2/pen dekatan-irestorative-justice-idalam-sistem-pidana-indonesiabroleh--jecky-tengens--sh- ). Restorasi meliputi pemulihan hubungan antara pihak korban dan pelaku. Pemulihan hubungan ini bisa didasarkan atas kesepakatan bersama antara korban dan pelaku. Pihak korban dapat menyampaikan mengenai kerugian yang dideritanya dan pelaku-pun diberi kesempatan untuk menebusnya, melalui mekanisme ganti rugi, Jurnal Ius Constituendum | Volume 3 Nomor 1 April 201877 
perdamaian, kerja sosial, maupun kesepakatankesepakatan lainnya. Kenyataan pada saat ini, restorative justice hanya memfokuskan pada peradilan anak yang melakukan tindak pidana sehingga penulis berpandangan bahwa ingin menggagas model restorative justice ini untuk menjadi solusi terbaik dalam kasus marital rape di Indonesia.

Jika menyelesaikan masalah marital rape melalui penegak hukum atau pengadilan, akan mengakibatkan perceraian dan tidak memberikan solusi yang tepat sehingga masyarakat seharusnya diberikan sosialisasi tentang adanya restorative justice untuk menyelesaikan permasalahan rumah tangga mereka agar tidak terjadinya perceraian. Dalam penyelesaian kasus marital rape melalui restorative justice membutuhkan pihak ketiga berupa keluarga, tokoh masyarakat, ataupun badan yang mengatur khusus tentang kasus marital rape di
Indonesia. Pihak ketiga disini dapat melakukan berbagai pendekatan yang komprehensif dan universal dalam menangani kasus-kasus yang dihadapi korban marital rape, yaitu melalui berbagai pendekatann antara lain psikologi, hukum, dan medis. Pendekatan psikologi dilakukan dengan cara terapi psikologi antara keduanya yaitu suami istri bisa dilakukan dengan cara pendekatan mediasi. Hasilnya, beberapa kasus marital rape dapat diselesaikan melalui jalur konsultasi (mediasi), dan hanya beberapa yang meneruskan ke jalur hukum.

Jalur hukum pada dasarnya dilakukan setelah pendekatan konsultasi dilalui oleh korban marital rape. selanjutnya terhadap hasil konsultasi tersebut korban mengambil keputusan untuk melanjutkan ke jalur hukum (pengadilan), dengan melakukan gugat cerai ke pengadilan. Jalur pengadilan ini ditempuh dalam rangka mengakhiri hubungan suami istri antara korban marital rape 
dengan pelaku marital rape, bukan dalam rangka melaporkan tindak pidananya. Dengan kata lain, marital rape dijadikan sebagai alasan untuk melakukan perceraian, bukan untuk mempidanakan suami yang telah melakukan marital rape. Adapun tindakan medis dilakukan apabila korban dalam hal ini korban marital rape membutuhkan penanganan medis, seperti, pengobatan, dan sebagainya.

\section{SIMPULAN DAN SARAN}

\section{SIMPULAN}

Kekerasan dalam rumah tangga atau domestic violence,dan lebih spesifik lagi wife abuse (kesewenangwenangan terhadap istri), tetaplah menjadi sebuah "rahasia perkawinan" yang sulit dijangkau oleh kekuasaan hukum mana saja. Beberapa alasan bisa dikemukakan di sini, di antaranya : pertama, kekerasaan dalam rumah tangga cenderung ditutupi karena rumah tangga adalah area "privat". Kedua, kekerasan dalam rumah tangga sering dianggap wajar karena memperlakukan istri sekehendak suami masih saja dianggap bahkan diyakini sebagai hak suami sebagai pemimpin dan kepala rumah tangga. Ketiga, kekerasan dalam rumah tangga itu terjadi dalam sebuah lembaga yang sah yaitu perkawinan. Konsep pendekatan restorative justice merupakan suatu pendekatan yang lebih menitik-beratkan pada kondisi terciptanya keadilan dan keseimbangan bagi pelaku tindak pidana serta korbannya sendiri. Mekanisme tata acara dan peradilan pidana yang berfokus pada pemidanaan diubah menjadi proses dialog dan mediasi untuk menciptakan kesepakatan atas penyelesaian perkara pidana yang lebih adil dan seimbang bagi pihak korban maupun pelaku. Dalam penyelesaian kasus marital rape melalui restorative justice membutuhkan pihak ketiga berupa keluarga, tokoh masyarakat, ataupun badan yang mengatur khusus 
tentang kasus marital rape di Indonesia. Pihak ketiga disini dapat melakukan berbagai pendekatan yang komprehensif dan universal dalam menangani kasus-kasus yang dihadapi korban marital rape, yaitu melalui berbagai pendekatann antara lain psikologi, hukum, dan medis.

\section{SARAN}

a. Bagi pemerintah pusat maupun daerah diharapkan dapat membentuk suatu badan/lembaga yang lebih komprehensif dalam rangka kegiatan sosialisasi agar masyarakat mengenal konsep restorative justice.

b. Para pihak yang berwenang diharapkan membuat peraturan perundangundangan mengenai kasus marital rape sehingga tidak ada lagi perdebatan mengenai suami memperkosa istri yang dikatakan bukan perbuatan melanggar hukum.

c. Edukasi tentang pendidikan seks sebelum pernikahan supaya para pasangan suami istri mengetahui tentang hak dan kewajibannya sebagai suami istri yang wajib saling cinta mencintai hormat menghormati, setia dan memberi bantuan lahir batin satu kepada yang lainnya dan suami wajib melindungi istrinya dan memberikan segala sesatu keperluan hidup berumah tangga sesuai dengan kemampuannya.

\section{DAFTAR PUSTAKA}

\section{LITERATUR}

Andy Dermawan. 2015. Tindak Pidana Marital Rape. Jakarta : Raja Grafindo Persada.

Aroma Elmina Martha. 2015. Eksploitasi Seksual Komersial Perempuan di Indonesia. Bandung : Refika Aditama.

Elli Nur Hayati. 2000. Panduan untuk Pendamping 
Perempuan

Korban

Kekerasan

Berwawasan

Konseling

Gender.

Yogyakarta : Pustaka Pelajar.

Johnny Ibrahim. 2006. Teori dan

Metodologi Penelitian Hukum

Normatif cetakan kedua.

Malang : Bayumedia

Publising.

Peter Mahmud Marzuki. 2010.

Penelitian Hukum. Jakarta :

Kencana Prenada Media

Group.

R. Soesilo. 1996. Kitab UndangUndang Hukum Pidana dan Penjelasannya. Jakarta : Rajawali Pers.

Siti Ruhaini Dzuhayatin. 2013.

Perlindungan Hukum Pidana

Marital Rape. Medan : Restu

Printing.

Utrech. 1987. Pengantar Dalam

Hukum Indonesia. Jakarta:

Ikhtiar.
Wahbah az-Zuhaili. 1989. Al-Fiqh al-islami wa Adillatuhu. Damaskus : Dar al-Fikr.

Undang-Undang Nomor 23 Tahun 2004 tentang Penghapusan Kekerasan Dalam Rumah Tangga

Undang-Undang Nomor 1 Tahun 1974 tentang Perkawinan

Kitab Undang-Undang Hukum Perdata (Burgerlijk Wetboek)

Kitab Undang-Undang Hukum Pidana

Kitab Undang-Undang Hukum Acara Pidana

HADIST DAN SURAT QUR'AN 
Iman muslim, Shahih Muslim

(Beirut : Dar al-Fikr, 1992), I :

663, Hadits Nomor 1436.

QS. Al - Baqarah (2) : 187 dan QS.

An-Nisa (4) : 19.

\section{WEBSITE}

http://www.hukumonline.com/berita

/baca/lt4e25360a422c2/pend

ekatan-irestorative-justice-i-

dalam-sistem-pidana-

indonesia-broleh--jecky-

tengens--sh- (diakses pada

tanggal 15 Januari 2018

pukul 09.10 WIB) 